\title{
RUSSIA'S BANKING SECTOR IN MAY 2013
}

\author{
M.Khromov
}

Banks' assets grew at a rate of 20.1\% in May 2013, being a slightly lower than in 2011 and 2012. In May, financial result of the banking business was found to be minimal since the fall of 2011. Household savings on bank accounts and deposits slowed down rapidly after three months of growth. A mid-term downtrend for retail lending was still there. The corporate segment of the lending market also saw slow growth rates. Banks became a beneficiary of the decline in the ruble exchange rate in June. In June 2013, growth in USD/RUB exchange rate may generate a net profit of more than $R b 30 b n$ for banks from revaluation of accounts.

Banking sector's assets increased $1.2 \%{ }^{1}$ in May 2013. Assets of small- and medium-sized banks, other than the top-30 largest banks, were growing much faster (by 1.6\%). Assets of state banks increased (by $1.2 \%$ ) in the banking sector in general, accounting for $55 \%$ of total bank assets. However, this result was achieved through more intensive growth (by 1.4\%) of Sberbank. Subsidiary foreign banks among the largest Russian banks saw a decline of $0.6 \%$ in their total assets in May.

Annual growth rates in bank assets stood at 20.1\% in May 2013, being slightly less but corresponding to the results achieved in 2011 (21.4\%) and 2012 (20.4\%), which means that bank assets saw stable growth rates in the post-crisis period.

Banks' equity capital grew at a much slower rate vs. assets. Book value of capital increased by $0.4 \%$, regulatory capital by $0.7 \%$ during the month, which means that bank assets growth was basically achieved through banks' borrowings rather than equity.

A share of state banks in total bank capital remained almost unchanged during the month, having remained at a level of $55.0 \%$.

The financial result of banking business amounted to $\mathrm{Rb} 68 \mathrm{bn}$ in May, a minimal value since the fall of 2011. Profit in the banking sector remained at a level of $\mathrm{Rb} 82 \mathrm{bn}$ on average over the last 12 months. An increase in contributions payable to the provisions for losses, which reached $\mathrm{Rb} 57 \mathrm{bn}$ in May, was basically responsible for profit shrinkage. It was a minimal value since January 2010, whereas the provisions increased by $\mathrm{Rb} 22 \mathrm{bn}$ per month on average over the last 12 months. The increase in contributions showed higher overall risk level bank assets were exposed to.

Return on assets in the banking sector fell to $1.6 \%$ and equity to $14.0 \%$ in May in response to the profit shrinkage. Annual financial efficiency values for the

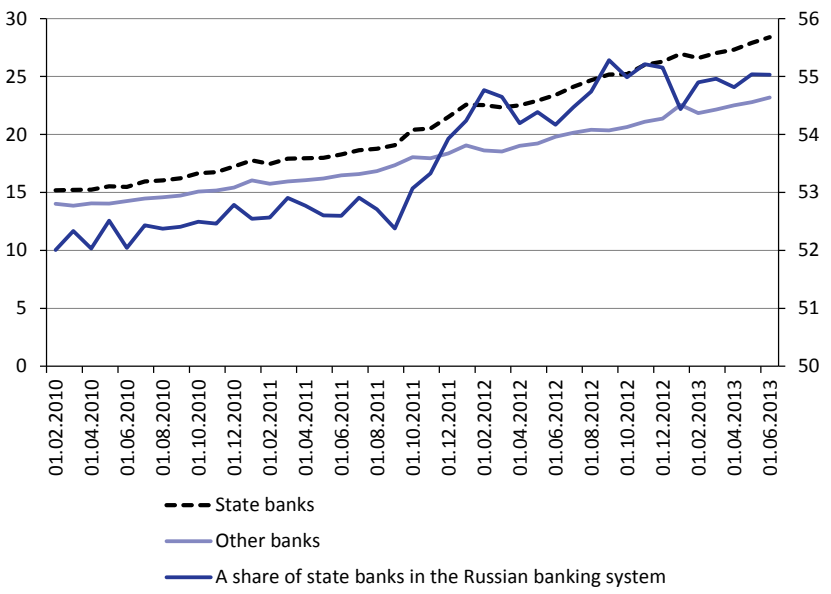

Fig. 1. Dynamics of state and other banks' assets (trillions of rubles), and a share of state banks in the assets (\%, right-hand scale)

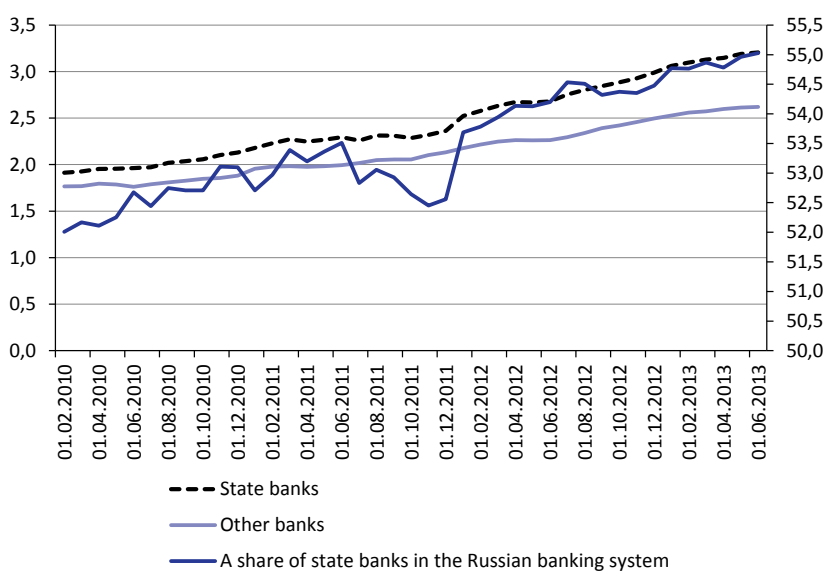

Fig. 2. Dynamics of state and other banks' equity capital (trillions of rubles), and a share of state banks in capital (\%, right-hand scale)

1 Hereinafter, unless otherwise indicated, growth rates in balance sheet figures are presented with allowance for revaluation of the foreign currency component. 
banking sector dropped to 2.1 and $18.1 \%$ respectively.

\section{Fundraising}

Growth in balances of retail bank accounts and deposits, which increased rapidly during the three preceding months (by $2.3 \%$ per month on average), slowed down abruptly in May, having contracted by $0.3 \%$. Curiously enough, such a situation was typical of this month during the past few years (in May 2012 retail accounts and deposits shrank by $0.2 \%$, in May 2011 by $0.3 \%$ ), which might be caused by a seasonal fall in the household income nominal value. In May, annual growth rate in retail bank accounts and deposits remained even higher (20.4\%) than at the beginning of the year (19.4\%).

The shrinkage of bank deposits in May had an effect on almost all groups of large banks in terms of certain groups of banks. Retail bank accounts and deposits in state banks shrank by $0.8 \%$, including $1.0 \%$ in Sberbank, $1.8 \%$ in foreign banks, $0.8 \%$ in large private banks, except for small- and medium-sized banks, where bank deposits saw an increase of $1.2 \%$ during the month.

Balances of corporate accounts increased by $1.7 \%$ in May. This type of bank liabilities saw a positive dynamics in less than just two months since the beginning of the year, the previous growth was reported in February. As a result, corporate custormers' bank accounts increased just $1.5 \%$ within five months since the beginning of the year. Annual growth rate in May increased up to $13.3 \%$, being much higher than the minimal level (9.6\%) in January, but kept being far behind the total dynamics of bank assets.

Regardless of the fact that overall growth in May was governed by increased balance of settlement and current accounts, term deposits $(54.6 \%$ as of the beginning of June 2013) kept prevailing in total corporate customers' funds.

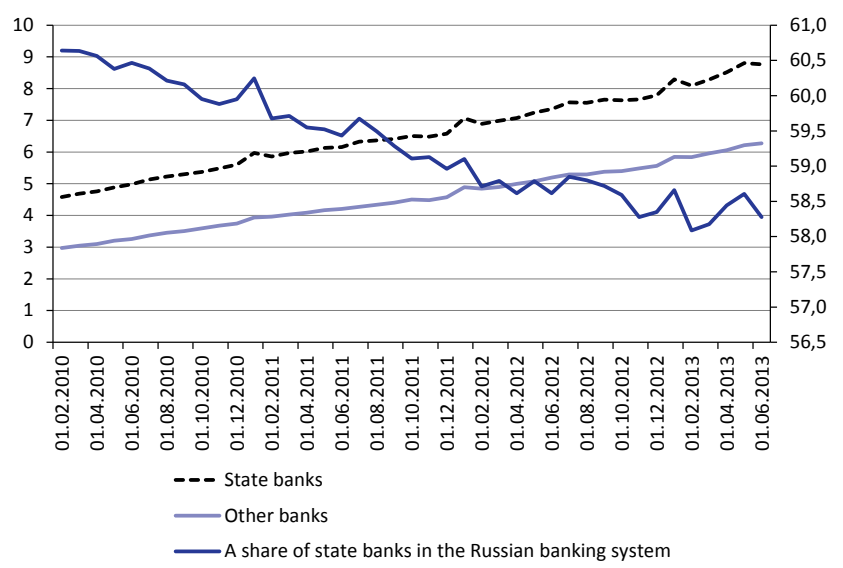

Fig. 3. Dynamics of state and other banks' retail deposits (trillions of rubles), and a share of state banks in the retail deposit market (\%, right-hand scale)

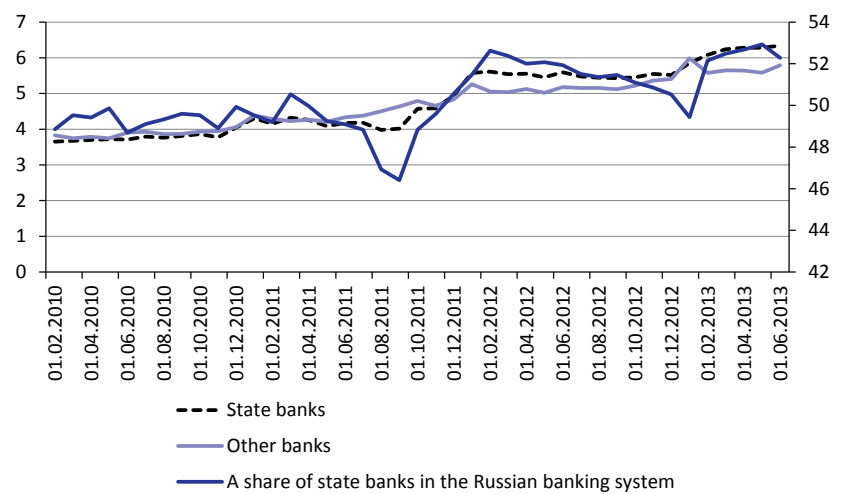

Fig. 4. Dynamics of corporate accounts with state and other banks (trillions of rubles), and a share of state banks in the corporate account market (\%, right-hand scale)

RUSSIAN BANKING SYSTEM'S STRUCTURE OF LIABILITIES (AT MONTH END), AS PERCENTAGE OF TOTAL

\begin{tabular}{|c|c|c|c|c|c|c|c|c|c|c|c|c|c|}
\hline & 2.08 & 12.09 & 12.10 & 12.11 & 03.12 & 06.12 & 09.12 & 12.12 & 01.13 & 02.13 & 03.13 & 04.13 & 05.13 \\
\hline Liabilitie & 28022 & 29430 & 33805 & 41628 & 41533 & 44266 & 45861 & 49510 & 48429 & 49165 & 49839 & 50693 & 51587 \\
\hline Equity & 14.1 & 19.3 & 18.7 & 16.9 & 17.5 & 16.8 & 16.9 & 16.2 & 16.8 & 16.7 & 16.7 & 16.6 & 16.5 \\
\hline Loans $\mathrm{fr}$ & 12.0 & 4.8 & 1.0 & 2.9 & 3.5 & 5.1 & 5.1 & 5.4 & 4.5 & 4.5 & 4.5 & 4.4 & 4.8 \\
\hline Interbank operations & 4.4 & 4.8 & 5.5 & 5.7 & 5.1 & 4.8 & 5.1 & 5.6 & 5.4 & 5.4 & 5.4 & 5.0 & 4.9 \\
\hline Foreign liabilities & 16.4 & 12.1 & 11.8 & 11.1 & 10.2 & 11.3 & 11.0 & 10.8 & 10.5 & 10.6 & 10.4 & 10.8 & 10.7 \\
\hline Retail accounts and $\mathrm{c}$ & 21.5 & 25.9 & 29.6 & 29.1 & 29.4 & 29.4 & 28.7 & 28.9 & 29.1 & 29.3 & 29.6 & 30.0 & 29.5 \\
\hline $\begin{array}{l}\text { Corporate accounts } \\
\text { and deposits }\end{array}$ & 23.6 & 25.9 & 25.7 & 26.0 & 25.7 & 24.0 & 23.3 & 24 & 24.1 & 24.2 & 23.9 & 23.4 & 23. \\
\hline $\begin{array}{l}\text { Accounts and deposits of } \\
\text { government agencies and } \\
\text { local government authorities }\end{array}$ & 1.0 & 1.0 & 1.5 & 2.3 & 1.4 & 1.5 & 2.5 & 1.6 & 1.1 & 1.0 & 1.4 & 1.9 & 2.0 \\
\hline Outstanding securities & 4.1 & 4.1 & 4.0 & 3.7 & 4.8 & 4.5 & 4.8 & 4.9 & 5.2 & 5.3 & 5.2 & 5.2 & 5.1 \\
\hline
\end{tabular}

Source: Central Bank of Russia, IET's estimates. 


\section{Loans issued}

Household debt to banks increased 2.5\% in May. Banks' retail credit portfolio grew up by $34.4 \%$ over 12 months. A monthly average downtrend for growth in retail lending was still there.

Different groups of banks showed similar growth rates in retail loans. Subsidiary foreign banks (2.2\%) showed minimal growth rates, whereas state banks showed maximum growth rates (2.6\%).

The quality of retail loans kept deteriorating. In May, overdue debt increased up to $4.4 \%$ of total loans, while accumulated provisions for losses grew up to $6.8 \%$. Post-crisis minimal values of both indicators were reached at 2012 year-end and stood at $4.1 \%$ and $6.1 \%$ respectively.

The corporate segment of the lending market kept growing at slow rates. Corporate credit portfolio grew up by $0.4 \%$ in May, and $14.0 \%$ over the last 12 months. Low growth rates in corporate lending resulted in a weird situation when retail lending was growing faster in nominal terms than corporate lending over more than a month. For example, household debt to banks increased by $\mathrm{Rb} 867 \mathrm{bn}$, whereas corporate debt increased just $\mathrm{Rb} 610 \mathrm{bn}$ since the beginning of the year.

Growth in corporate lending at largest banks almost stopped $(+0.1 \%)$ in May. Credit portfolio shrank by $2.8 \%$ at foreign banks, whereas state banks saw insignificant shrinkage of their credit portfolio $(0.5$ and $0.3 \%$ respectively). It was small- and mediumsized banks that were responsible for the overall growth, where debt on corporate loans increased by $1.6 \%$.

The quality of corporate loans remained unchanged year-to-date. A share of overdue debt in May was just 0.1 p.p. higher than as of the beginning of the year (4.6 and $4.7 \%$ of total loans respectively), and the ratio of provisions for losses to total debt on loans remained unchanged over the last five months (7.5\%).

In May, banks invested basically in foreign assets. For example, retail loans increased by $\mathrm{Rb} 225 \mathrm{bn}$, whereas foreign assets increased more than $\$ 12 b n$. In May, foreign liabilities contracted by $\$ 2 b n$, whereas net foreign assets in the banking sector increased by $\$ 14,4 \mathrm{bn}$. Foreign currency position of banks saw a much bigger growth, i.e. an excess of foreign currency assets over foreign currency liabilities: from $\$ 27,2 \mathrm{bn}$ as of May 1 to $\$ 43,3 \mathrm{bn}$ as of June 1 . Therefore, one may conclude that banks became a beneficiary of the decline in the ruble exchange rate in June. In June 2013, growth in USD/RUB exchange rate may generate more than $\mathrm{Rb} 30 \mathrm{bn}$ of net profit for banks from revaluation of accounts.

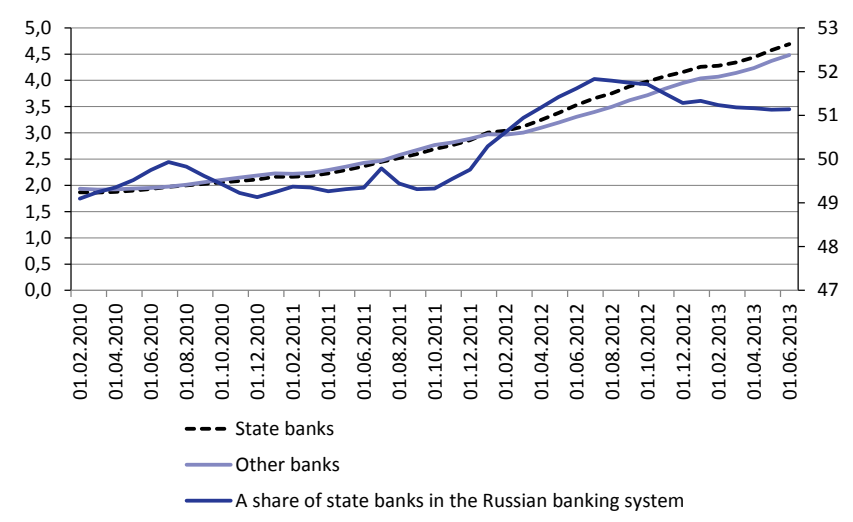

Fig. 5. Dynamics of state and other banks' retail loans, (trillions of rubles), and a share of state banks in the retail loan market (\%, right-hand scale)

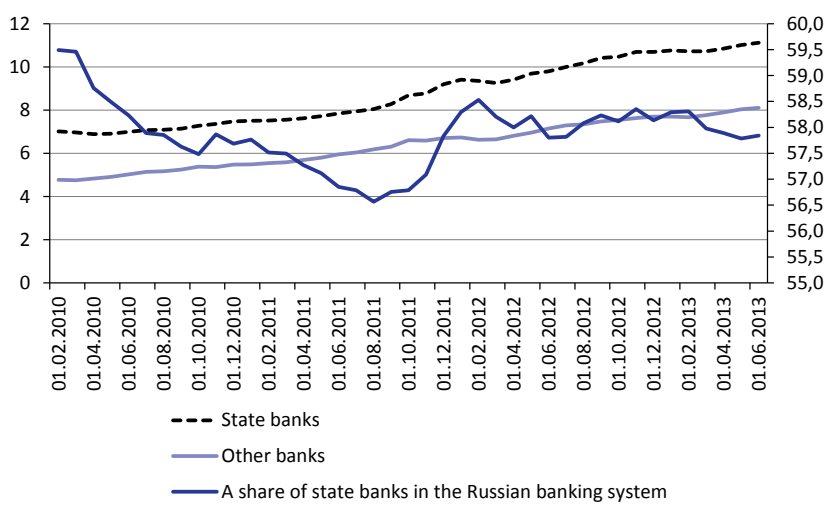

Fig. 6. Dynamics of state and other banks' corporate loans (trillions of rubles), and a share of state banks in the corporate loan market (\%, right-hand scale)

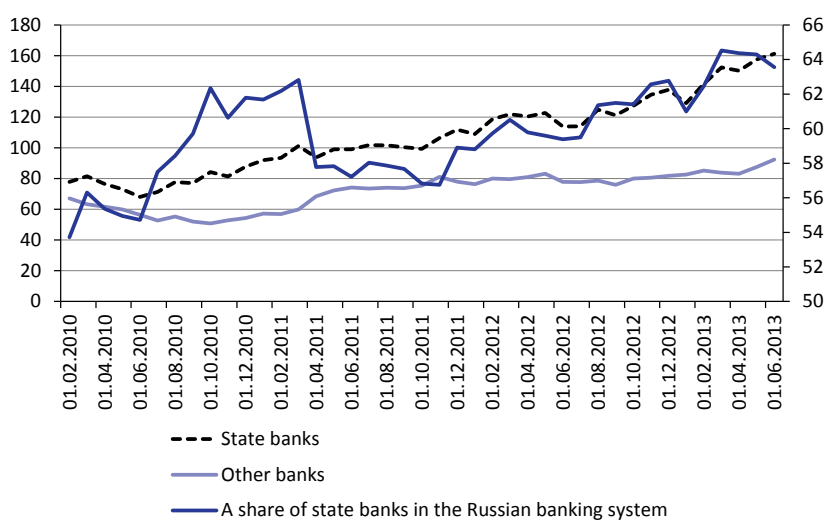

Fig. 7. Dynamics of state and other banks' foreign assets (billions of US dollars), and a share of state banks in total foreign assets (\%, right-hand scale) 
Table 2

Russian banking system's structure of assets (at month end), as percentage of total

\begin{tabular}{|c|c|c|c|c|c|c|c|c|c|c|c|c|c|}
\hline & 12.08 & 12.09 & 12.10 & 12.11 & 03.12 & 06.12 & 09.12 & 10.12 & 01.13 & 02.13 & 03.13 & 04.13 & 05.13 \\
\hline Assets, billions of rubles & 28022 & 29430 & 33805 & 41628 & 41533 & 44266 & 45861 & 47096 & 48429 & 49165 & 49839 & 50693 & 51587 \\
\hline $\begin{array}{l}\text { Cash } \\
\text { and precious metals }\end{array}$ & 3.0 & 2.7 & 2.7 & 2.9 & 2.4 & 2.5 & 2.6 & 2.6 & 2.6 & 2.5 & 2.5 & 2.7 & 2.4 \\
\hline $\begin{array}{l}\text { Deposits in the } \\
\text { Bank of Russia }\end{array}$ & 7.5 & 6.9 & 7.1 & 4.2 & 3.2 & 3.0 & 2.8 & 2.7 & 2.9 & 3.1 & 3.3 & 3.0 & 3.1 \\
\hline Interbank operations & 5.2 & 5.4 & 6.5 & 6.4 & 6.2 & 5.8 & 5.8 & 6.1 & 6.7 & 6.6 & 6.4 & 6.1 & 6.0 \\
\hline Foreign assets & 13.8 & 14.1 & 13.4 & 14.3 & 14.2 & 14.2 & 13.9 & 14.3 & 14.0 & 14.6 & 14.5 & 15.0 & 15.6 \\
\hline Retail sector & 15.5 & 13.1 & 13.0 & 14.4 & 15.3 & 16.0 & 16.8 & 16.8 & 17.3 & 17.3 & 17.4 & 17.7 & 17.8 \\
\hline Corporate sector & 44.5 & 44.5 & 43.6 & 44.0 & 44.4 & 43.6 & 43.4 & 42.9 & 42.3 & 42.1 & 41.9 & 41.5 & 40.9 \\
\hline State & 2.0 & 4.2 & 5.1 & 5.0 & 4.9 & 3.8 & 3.3 & 3.2 & 3.7 & 3.3 & 3.2 & 2.9 & 2.8 \\
\hline Property & 1.9 & 2.7 & 2.6 & 2.3 & 2.4 & 2.3 & 2.3 & 2.3 & 2.3 & 2.3 & 2.2 & 2.2 & 2.2 \\
\hline
\end{tabular}

Source: Central Bank of Russia, IET's estimates. 